\title{
Influence of environmental variables on the larval stages of anchovy, Engraulis encrasicolus, and sardine, Sardinops sagax, in Algoa Bay, South Africa
}

\author{
David Costalago (iD) - Paige Potter • Paula Pattrick • \\ Nadine A. Strydom
}

Received: 28 February 2017 / Accepted: 30 October 2017 / Published online: 14 November 2017

(C) The Author(s) 2017. This article is an open access publication

\begin{abstract}
We investigated the environmental drivers of larval abundance of anchovy Engraulis encrasicolus and sardine Sardinops sagax in Algoa Bay, Eastern Cape (South Africa). This study comprised a predrought post-drought time period, comparing the responses of the fish larvae to different factors before and after the drought. The current study presents, for the first time, which environmental variables are affecting the anchovy and sardine larvae populations in the region. Easterly wind speed and zooplankton density were the only environmental variables that presented a significant change between the pre- and post-drought periods, increasing after the drought. Generalized additive models (GAMs) were used in order to explore the effects that environmental factors might have in the abundance of anchovy and sardine larvae in Algoa Bay. Specifically, the GAM that best explained the deviance of the anchovy larvae dynamics included the
\end{abstract}

Electronic supplementary material The online version of this article (https://doi.org/10.1007/s10641-017-0693-z) contains supplementary material, which is available to authorized users.

D. Costalago ( $\square)$

Department of Ecology, Environment and Plant Sciences, Stockholm University, SE-10691 Stockholm, Sweden e-mail: nauplius97@gmail.com

D. Costalago $\cdot$ P. Potter $\cdot$ P. Pattrick $\cdot$ N. A. Strydom Department of Zoology, Nelson Mandela Metropolitan University, Port Elizabeth, South Africa

\section{P. Pattrick}

South African Institute for Aquatic Biodiversity (SAIAB),

Grahamstown, South Africa covariates rainfall, easterly wind speed, $\mathrm{Chl} a$ concentration, sardine larvae abundance and the interactions $S S T *$ Chla and $\operatorname{sard}^{*} S S T$. The GAM best explaining sardine larvae abundance included only the easterly wind speed as a covariate. This model showed that there was a positive relationship between the higher values of wind speed and sardine larvae abundance.

Keywords Climate shifts · GAMs · Ichthyoplankton · Recruitment $\cdot$ Small pelagic fish

\section{Introduction}

Fluctuations in the small pelagic fish populations have a major impact on the ecosystem and on fisheries (Cury et al. 2000). Therefore, an understanding of their dynamics is essential. The response of small pelagic fish species to the environmental variability is manifested as inter-annual oscillations in recruitment success (Cury and Roy 1989; Cushing 1996; Bakun 2006); thus, environmental regime shifts have resulted in abundance and distributional changes between sardine and anchovy in most upwelling areas worldwide (Roy et al. 2007; Coetzee et al. 2008). Recruitment variability stands as one of the major issues in fisheries research (Houde 2008). Because the larval fish stages have the highest vulnerability to mortality, these life-stages are the principal determinant of recruitment (Caley et al. 1996; Bergenius et al. 2002).

The combination of physical factors and food availability has become widely accepted as the main 
environmental determinant of larval fish survival (Leggett and Deblois 1994; Cushing 1996; Costalago et al. 2011), and thereby fish population dynamics (Beaugrand and Reid 2003). Nevertheless, new insights have demonstrated that recruitment variability can result from numerous abiotic and biotic processes, including fishing, maternal condition and other anthropogenic factors, operating on many different spatio-temporal scales, and represents an integrated process acting throughout early life stages of fishes (Houde 2008). With the increasing threat of global climate change, there is an urge to understand which environmental factors influence the early stages of key species like sardine and anchovy and thereby further comprehend how these factors alter population growth.

Algoa Bay in the Eastern Cape, South Africa, is an area in which both sardine and anchovy adults are found and where their larvae are known to complete their pelagic phase in the bay (Pattrick and Strydom 2008). The influence of environmental variables on the fluctuations between sardine and anchovy have largely been studied in the Benguela Current system (Shannon et al. 1984; van der Lingen et al. 2006), in the western coast of South Africa. However, there is a particular lack of knowledge regarding the dynamics of their larval stages in the Agulhas Current system (Hutchings et al. 2002; Pattrick and Strydom 2008), which flows southwards and then southwestwards along the eastern and southern coasts of South Africa.

Thus, it is urgent to provide information about the state of the pelagic ecosystem in Algoa Bay, and in particular for anchovy and sardine, as these species are extremely relevant economically and ecologically. Algoa Bay also hosts important populations of marine top predators, such as South African fur seals, bottlenose and common dolphins, cape gannets and the world's largest African penguin colony (Pichegru et al. 2010), which feed predominantly on small pelagic fish (Batchelor and Ross 1984; David 1987; Young and Cockcroft 1994). Moreover, there is an ongoing discussion about the potential impacts that the prospective finfish farming activity planned in Algoa Bay (Bloom 2012; Hutchings et al. 2013). Potential impacts of tourism (shark cage diving, whale watching, recreation fishing), on pollution levels, fishing activities, boat traffic and existing and planned Marine Protected Area in the bay, are currently being assessed (Bloom 2012, 2013).

With this work, we thus intend to elucidate what environmental (among wind, rainfall, water temperature and chlorophyll $a$ as an indicator of productivity) and other factors (food availability, i.e. zooplankton density, and larval fish abundance) are the major regulators of the abundance of the larvae of anchovy and sardine in Algoa Bay.

\section{Material and methods}

\section{Study site}

Algoa Bay is characterized by important seasonal environmental fluctuations (Pattrick and Strydom 2008; Goschen et al. 2012), combined with complex circulation as the Agulhas Current leaves the coast following the shelf break (Goschen and Schumann 1988; Boyd et al. 1992).

Algoa Bay (Fig. 1) is situated on the southeast coast of South Africa, on the eastern limit of the Agulhas Bank. The Agulhas Current flows south-westward, around $80 \mathrm{~km}$ offshore of Algoa Bay, bringing nutrient poor, tropical waters (Lutjeharms 1981). The bay is encompassed by Cape Recife in the west and Woody Cape in the east, and has a wide mouth $(\sim$ $90 \mathrm{~km}$ ) which allows free exchange of water between the bay and the Agulhas Bank waters (Goschen and Schumann 1994, 2011). The shelf width extends for $55 \mathrm{~km}$, reaching a maximum depth of $\sim 73 \mathrm{~m}$ (Bremner 1991).

Algoa Bay has a warm temperate climate with sea surface temperature ranging $10-24{ }^{\circ} \mathrm{C}$ throughout the year (Smit et al. 2013). The area experiences an annual rainfall of 400 to $800 \mathrm{~mm}$ per annum (Dent et al. 1987), with peaks of rainfall in autumn and spring (Whitfield 1998). However, between 2008-2010 Algoa Bay received $<250-300 \mathrm{~mm}$ per annum of rainfall, which classified those years as a drought period. During summer, the water column is stratified but the winds during winter largely contribute to the mixing of water such that little or no stratification is evident (Goschen 1991). Wind seasonality is highly variable between the winter and summer months. Strong easterly winds dominate in summer and these winds induce local upwelling events (Schumann et al. 1991). The Sundays and Swartkops Rivers play an important role in the runoff and input of nutrients and energy into the nearshore coastal ecosystem of the bay (Lukey et al. 2006; Pattrick and Strydom 2008). 


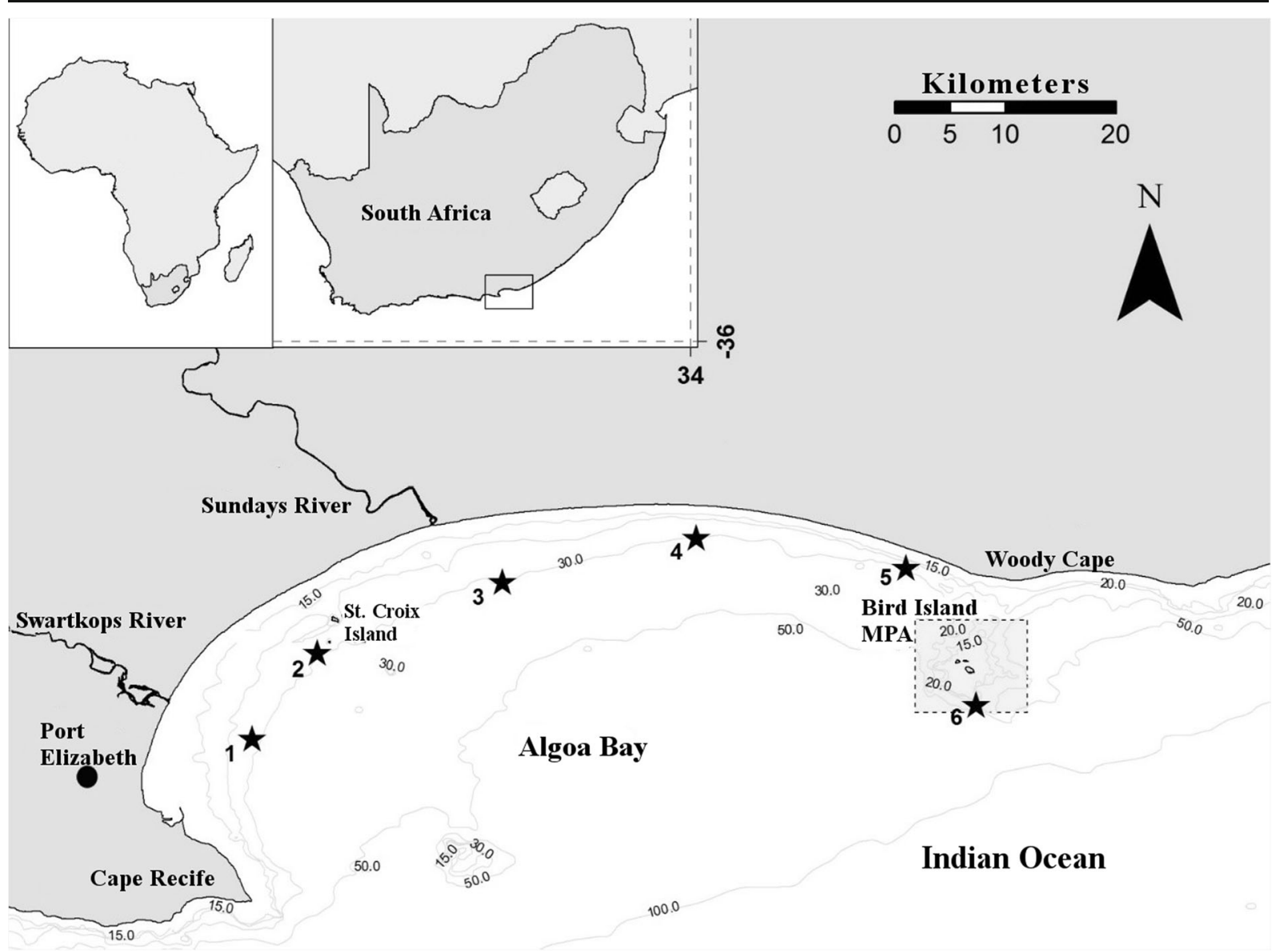

Fig. 1 Geographic location and map of Algoa Bay, South Africa. The stations where the zooplankton and larval fish were caught are marked by the stars

Larval fish and mesozooplankton collection

From March 2005 to January 2007 (i.e. before the drought period), samples of larval fishes were collected once a month during two successive months per season (March and April as autumn months, June and July as winter months, September and October as spring months, and December and January as summer months), in order to determine seasonal trends in ichthyoplankton (Pattrick and Strydom 2008). At each station (Fig. 1), larvae were collected by means of skiboat based plankton tows using a set of bongo nets. Plankton nets were 3.5-4 $\mathrm{m}$ long with a mouth diameter of $750 \mathrm{~mm}$, and a mesh size of $500 \mu \mathrm{m}$. A calibrated flowmeter was fitted to the $12 \mathrm{~mm}$ thick stainless steel frame of each net to calculate the volume of water sampled. The nets were pulled parallel to shore using a stepped oblique tow at a speed of 2 knots. Bottom, mid and subsurface waters were sampled for $2 \mathrm{~min}$ each, and including hauling, each tow lasted approximately $8 \mathrm{~min}$.

After the 2008-2010 drought period, larval fish were collected monthly from August 2010 to May 2013 within the bay as part of an ongoing plankton monitoring programme initiated by the South African Environmental Observation Network (SAEON). Larvae were sampled monthly at the six stations (Fig. 1), also by means of ski-boat based plankton ring net tows as described above for the pre-drought period.

Alongside with the fish larvae, zooplankton samples were collected. Zooplankton was sampled using a WP2 style net (420 mm diameter, $90 \mu \mathrm{m}$ mesh size and $2 \mathrm{~m}$ long). The samples were fixed on site in $10 \%$ formalin. The zooplankton was measured as dry weight $\left(\mathrm{mg} / \mathrm{m}^{3}\right)$.

In the laboratory larval fish were sorted and identified to the lowest possible taxonomical level (Olivar and Shelton 1993) and standard length (SL) measured to the closest $0.1 \mathrm{~mm}$ using an eye piece micrometer. The 
abundance of sardine and anchovy larvae for each sample was estimated as density using the following formula:

Density $=100^{*} \frac{\text { No.of larvae }}{(\text { flow meter revolutions } \div \text { calibration value in } \mathrm{m} 3)}$

\section{Environmental factors}

Rainfall, wind speed and wind direction were obtained from the South African Weather Service (SAWS) for Coega $\left(33^{\circ} 48^{\prime} 18^{\prime \prime} \mathrm{S}, 25^{\circ} 41^{\prime} 11^{\prime \prime} \mathrm{E}\right.$; Fig. 1) during the study period. The mean wind speed of all days with wind directions from $56.24^{\circ}$ to $123.74^{\circ}$ (taken as easterly components, which induce upwelling in the bay) was calculated and squared, thereby producing a pseudo-stress index $\left(\mathrm{m}^{2} / \mathrm{s}^{2}\right)$ that represented the average speed of all easterly winds in that month (Daskalov et al. 2003). Average monthly rainfall (mm) was used.

Satellite data from the NASA Earth Observations satellite platform (MODIS-Aqua Mission; www.neo. sci.gsfc.nasa.gov) provided information on Sea surface temperature (SST) and chlorophyll $a$ concentration. Chlorophyll $a$ concentrations were recorded as monthly averages $\left(\mathrm{mg} / \mathrm{m}^{3}\right)$ at a $1 \times 1 \mathrm{~km}$ scale. Chlorophyll $a$ is taken as a representation of phytoplankton biomass (Shannon et al. 1984). Both chlorophyll $a$ and SST data were retrieved on March 2015. Mesozooplankton concentrations in the bay, collected at the same six sites where the larval fish densities were sampled, were obtained from the SAEON (see detailed methodology in Dali 2011).

\section{Data analyses}

Statistical analyses were performed with the R software v. 3.2.0. Significance levels of $p<0.05$ were used. All data were tested for normality using the Shapiro-Wilk test. Wilcoxon tests were used to determine differences in densities in anchovy and sardine larvae, in zooplankton density and in the environmental variables between 2005-2007 (before the drought) and 2010-2013 (after the drought ended).

To assess which environmental factors were affecting larval anchovy and sardine dynamics, Generalised Additive Models (GAMs), as implemented in the $m g c v$ library of R (Wood 2001). Easterly wind speed, rainfall, mesozooplankton density, sea surface temperature (SST), chlorophyll $a$ concentration and the other larval fish species abundance (i.e., sardine as a covariate in the anchovy model and vice-versa) were used as covariates. In a previous analysis, no correlation among covariates was detected (Suppl. Fig. 1) All the interactions between variables that resulted significant at $p<0.01$ in an ANCOVA test were included in the initial GAMs of the larval abundance. Then, the covariates (and interactions) whose partial effect had the lowest significance level (i.e. the covariate with the highest $p$-value) were removed one by one. The family link used was quasiPoisson to accommodate for the dispersion and zerovalues. No lag time was used between the larval density and the environmental factors as during sampling the larval fish were only a few days old. Effective covariates were selected following Wood (2001). Covariates were deleted from the models if the following three criteria were met: (i) the estimated degrees of freedom was close to 1 ; (ii) the confidence interval was zero everywhere; and (iii) the generalized cross validation (GCV) score decreased when the term was dropped. The GCV method was used to select a best fit model, with lower GCV score being better.

\section{Results}

Larval and mesozooplankton abundance

Larval anchovy abundance was much higher than larval sardine (Fig. 2). Larval anchovy had similar abundance throughout the year, but showed the highest abundance in spring while larval sardine had the highest densities per month in winter. Larval anchovy increased significantly between the two sampling periods $(\mathrm{F}=0.05$, $p<0.0001 ; t=-4.44, \mathrm{p}<0.0001)$, while larval sardine densities did not change significantly between 2005 2007 and 2010-2013 ( $\mathrm{F}=0.69, p=0.237 ; t=-0.1$, $p=0.445$ ). Anchovy larvae were present during $88.0 \%$ of the sampling trips and averaged $1.7 \pm 3.3$ larvae/ $100 \mathrm{~m}^{3}$ during 2005-2007 and 14.2 \pm 14.1 larvae/ $100 \mathrm{~m}^{3}$ during 2010-2013. The combined average for all the samples for anchovy larvae was $9.7 \pm 12.9$ larvae/ $100 \mathrm{~m}^{3}$ per sample (range $0-45$ larvae $/ 100 \mathrm{~m}^{3}$ per month). Sardine larvae were present during $70.9 \%$ of the sampling trips and averaged $1.4 \pm 2.2$ larvae $/ 100 \mathrm{~m}^{3}$ per sample when present (range $0-9.4$ larvae $/ 100 \mathrm{~m}^{3}$ per month). Total length of anchovy and sardine larvae ranged from $1.6-10.5 \mathrm{~mm}$ and $3-8.5 \mathrm{~mm}$, respectively. Mesozooplankton density was highest in summer 


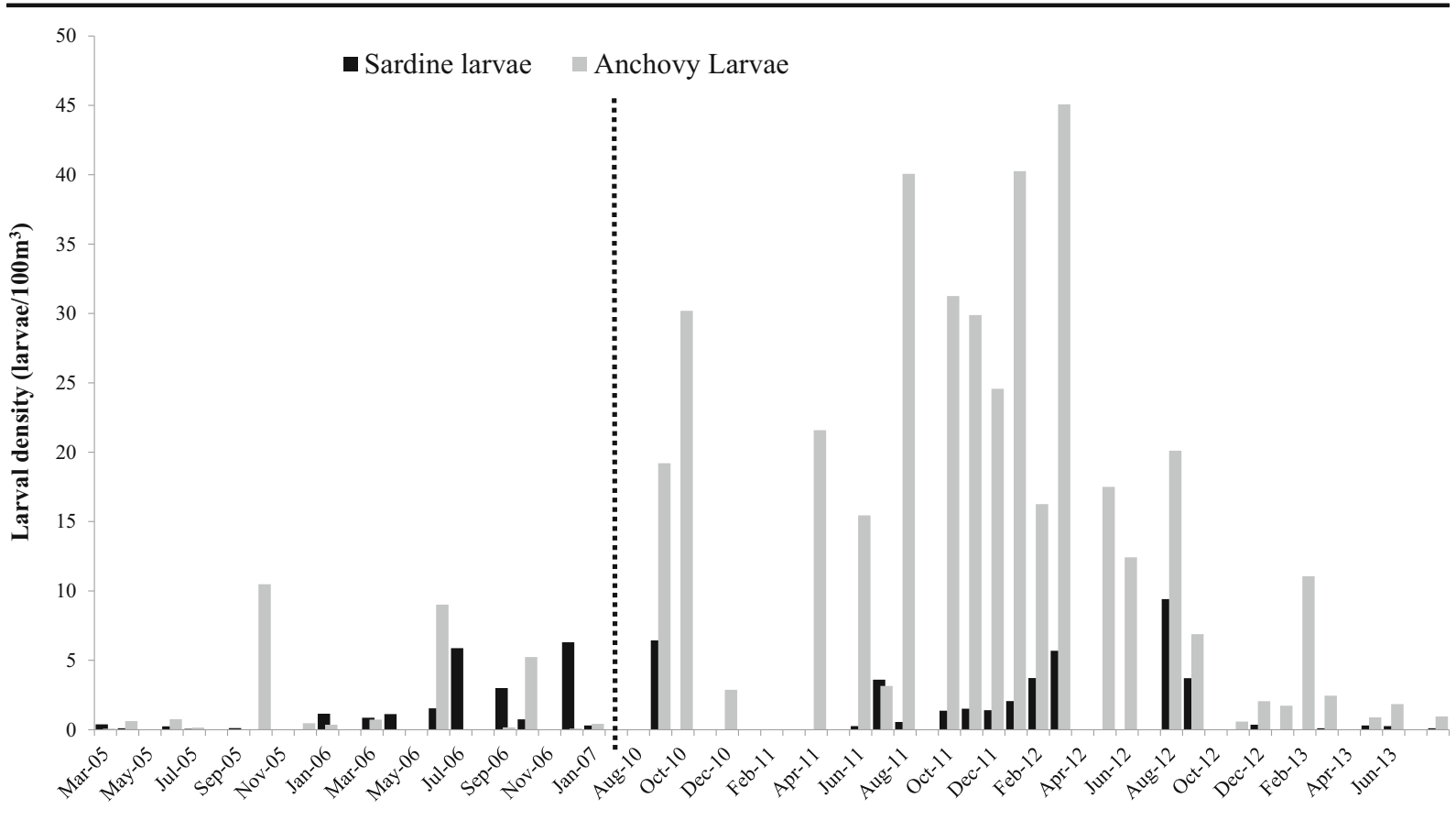

Date of sampling

Fig. 2 Larval density for sardine and anchovy per month for March 2005 - January 2007 and August 2010 - July 2013 in Algoa Bay, Eastern Cape. Larval fish were not sampled in the bay

with $54.0 \pm 31.9 \mathrm{mg} / \mathrm{m}^{3}$ on average, and lowest in winter with a mean of $25.0 \pm 12.7 \mathrm{mg} / \mathrm{m}^{3}$.

The differences between the pre-drought and postdrought periods were significant in anchovy and zooplankton density (Fig. 3).

\section{Environmental variability}

Before the drought (2005-2006), the mean monthly rainfall in the region was $39.05 \pm 24.16 \mathrm{~mm} /$ month. During the drought, monthly rainfall was between 20.5- $24.36 \mathrm{~mm} / \mathrm{month}$. The years 2011 and 2012, which saw the beginning of the post-drought period, had more than double the rainfall than during the drought, with $55.21 \mathrm{~mm} / \mathrm{month}$ in 2010-2011 and $73.21 \mathrm{~mm} / \mathrm{month}$ in 2012-2013. Annual easterly wind index ranged from $7.94-22.8 \mathrm{~m}^{2} / \mathrm{s}^{2}$ between $2005-$ 2013 (Suppl. Fig. 2). Monthly easterly winds were highest in spring and summer, with much weaker winds dominating autumn and winter. These strong winds were closely followed by peaks in chlorophyll $a$ in autumn, spring and summer. Chlorophyll $a$ ranged from $3.3 \pm 0.1 \mathrm{mg} / \mathrm{m}^{3}$ in winter to $6.9 \pm 1.03 \mathrm{mg} / \mathrm{m}^{3}$ in autumn (Suppl. Fig. 2). Across all years, monthly between these two periods. The vertical dotted line separates both periods (pre-drought and post-drought)

concentrations ranged between $0.65-22.4 \mathrm{mg} / \mathrm{m}^{-3}$ (Suppl. Fig. 2). Sea surface temperature ranged 17.24$23.15{ }^{\circ} \mathrm{C}$ in the pre-drought period, and $16.69-23.45^{\circ} \mathrm{C}$ in the post-drought period (Suppl. Fig. 2).

Regarding the differences between the pre-drought and post-drought periods, significance $(p<0.05)$ was found only in the easterly wind speed (Fig. 3).

Relationships between environmental factors and larval abundances

The interactions that presented a significant effect $(p<0.01)$ on anchovy larvae abundance were SST and chlorophyll $a$ and sardine larvae abundance and SST. These interactions were included in the initial GAM model for anchovy (Table 1). A smoother was added to the covariates (or interactions) that presented a nonlinear effect (Table 1).

To explain anchovy larvae abundance, there were two GAMs with very similar GCV values: A2 and A3 (GCV = 142.12 and 142.07, respectively). A2 included the terms rain, wind, Chla, sard, SST, SST*Chla and sard*SSTand explained $46.3 \%$ of the variance (Table 1 ), whereas A3 included the terms rain, wind, Chla, sard, 

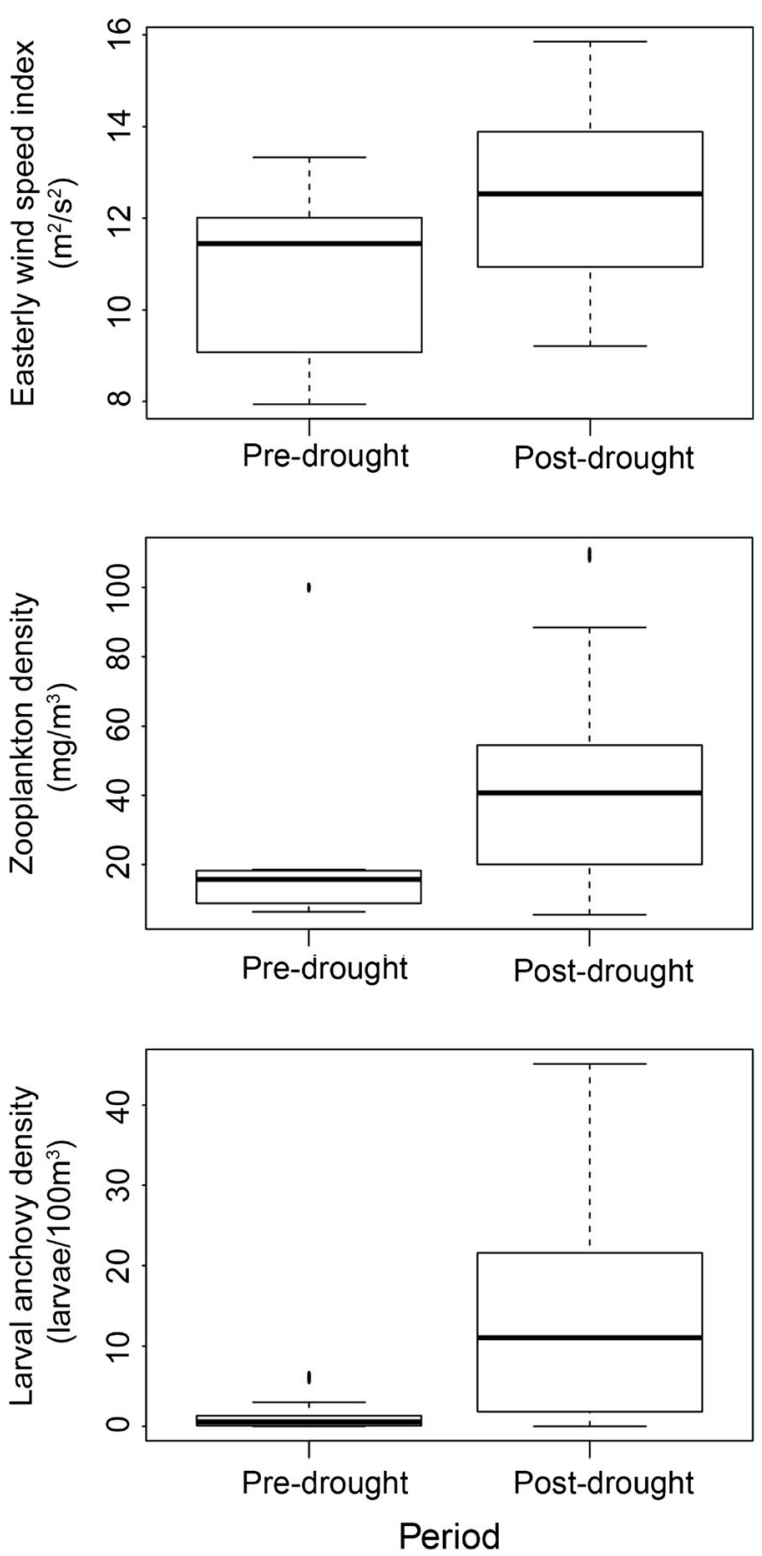

Fig. 3 Boxplots showing median (bold line), first and third quartiles (box) and 95\% confidence intervals (whiskers) for the variables that were significantly different between the pre-drought and post-drought periods: easterly wind speed $(p<0.05)$, zooplankton density $(p<0.01)$ and larval anchovy density $(p<0.001)$

SST*Chla and $\operatorname{sard*SST}$ and explained $43 \%$ of the variance (Table 1). An ANOVA test did not show significant differences between these two models. We chose the A3, which had the lowest GCV value and a lower number of terms than A2, as the best fit. The sard term (sardine larvae abundance) was the most significant explanatory variable of the best-fit model, followed by wind speed.
Looking at the best-fit model, larval anchovy abundance was higher at intermediate rainfall levels (approx. $100 \mathrm{~mm} / \mathrm{month})$. Concurrently, higher values of wind speed and Chl $a$ concentration had a positive effect on anchovy larvae abundance (Fig. 4A). Anchovy larvae abundance was higher at the lowest levels of sardine larvae abundance (Fig. 4A). When higher than 80, interaction $S S T^{*}$ Chla had a negative effect on the anchovy larvae population; contrarily, the interaction $\operatorname{sard} * S S T$ had a positive effect on the anchovy larvae abundance (Fig. 4A).

The ANCOVA indicated that none of the possible covariate interactions presented a significant effect on sardine abundance. Rainfall and wind were the only variables that presented a non-linear effect on sardine abundance and thus a smoother was added to each variable in the initial model. The GAM for sardine larvae abundance with the lowest GCV score (8.31) was S6, which explained $41.9 \%$ of the deviance and included only the term wind (Table 1). This GAM best explaining sardine larvae abundance (Fig. 4B) showed that there was a positive relationship between the higher values of easterly wind speed $\left(>15 \mathrm{~m}^{2} / \mathrm{s}^{2}\right)$ and sardine larvae abundance.

The residuals of the best models (with the lowest GCV) for both anchovy and sardine abundance response variables were visually explored for violations from the model assumptions. There was no significant linear trend in residuals plotted against the predicted response, and residuals appeared to be normally distributed in the case of the best fit models for anchovy and sardine larvae abundance (Suppl. Fig. 3). No autocorrelation is evident for the data.

\section{Discussion}

The results of this study show that, following a drought period of about two years in Algoa Bay, anchovy larvae become significantly more abundant than before the drought happened, whereas the sardine larvae population in the region did not show any significant change in size after the drought period. These two species of small pelagic fish play a particularly important role in the pelagic food web (Cury et al. 2000; Pikitch et al. 2014), as well as they are commercially relevant (Pikitch et al. 2014). Thus, it is important to identify which factors might be affecting the dynamics of the early life stages of their populations in the region. The 
Table 1 Forward stepwise General Additive Models of fish larvae abundance and selected environmental variables in Algoa Bay during the entire period of study

\begin{tabular}{|c|c|c|c|c|c|c|c|c|}
\hline Models & $\begin{array}{l}\text { Deviance } \\
\text { explained }\end{array}$ & $\mathrm{n}$ & Estimate & $\begin{array}{l}\text { Std. } \\
\text { Error }\end{array}$ & $\begin{array}{l}\text { t- } \\
\text { value }\end{array}$ & $\mathrm{p}(\mathrm{z})$ & $r^{2}$ & GCV \\
\hline \multicolumn{9}{|l|}{ Response: Anchovy larvae abundance } \\
\hline $\begin{array}{l}\text { A1.- (rain) + wind + (zooplk })+ \text { Chla* + sard + } \\
\text { SST + SST:Chla* + sard:SST }\end{array}$ & $50.7 \%$ & 40 & 9.301 & 1.638 & 5.678 & $<0.0001$ & 0.35 & 144.64 \\
\hline $\begin{array}{l}\text { A2.- }(\text { rain })+\text { wind* }+ \text { Chla* + sard* + SST + } \\
\text { SST:Chla* + sard:SST* }\end{array}$ & $46.3 \%$ & 42 & 9.772 & 1.635 & 5.976 & $<0.0001$ & 0.34 & 142.12 \\
\hline $\begin{array}{l}\text { A3.- (rain) + wind } *+\text { Chla }^{*}+\text { sard }^{* *}+ \\
\text { SST:Chla } * \text { sard:SST } * *\end{array}$ & $43 \%$ & 42 & 9.772 & 1.660 & 5.887 & $<0.0001$ & 0.32 & 142.07 \\
\hline A4.- wind $*+$ Chla* + sard* + SST:Chla* + sard:SST** & $38.3 \%$ & 42 & 9.772 & 1.695 & 5.766 & $<0.0001$ & 0.29 & 142.59 \\
\hline A5.- Chla* + sard* + SST:Chla* + sard:SST** & $29.9 \%$ & 42 & 9.772 & 1.775 & 5.506 & $<0.0001$ & 0.22 & 151.19 \\
\hline A6.- sard + SST:Chla + sard:SST* & 23.1 & 42 & 9.772 & 1.844 & 5.300 & $<0.0001$ & 0.16 & 160.32 \\
\hline \multicolumn{9}{|l|}{ Response: Sardine larvae abundance } \\
\hline S1.- (rain) + (wind $)+$ zooplk + Chla + anch $+($ SST $)$ & $43.3 \%$ & 40 & 1.690 & 0.398 & 4.247 & 0.0002 & 0.22 & 8.89 \\
\hline S2.- (rain) + (wind)* + zooplk + Chla + (SST) & $41.9 \%$ & 41 & 1.649 & 0.387 & 4.256 & 0.0001 & 0.23 & 8.31 \\
\hline S3.- (wind) + zooplk + Chla + (SST) & $35.5 \%$ & 41 & 1.649 & 0.394 & 4.187 & 0.0002 & 0.21 & 7.99 \\
\hline S4.- (wind)* + zooplk + Chla & $24.6 \%$ & 41 & 1.649 & 0.404 & 4.079 & 0.0002 & 0.16 & 7.59 \\
\hline S5.- (wind)* + zooplk & $23.5 \%$ & 42 & 1.611 & 0.393 & 4.099 & 0.0002 & 0.12 & 7.14 \\
\hline S6.- (wind)* & 28.4 & 44 & 1.573 & 0.368 & 4.268 & 0.0001 & 0.21 & 6.73 \\
\hline
\end{tabular}

The best model for each species is highlighted in bold. Covariates with smoother are presented in brackets. The significance of each term in each model is marked with $*(\mathrm{p}<0.05)$ and $* *(\mathrm{p}<0.01)$

anch, anchovy larvae density; Chla, chlorophyll a concentration; rain, monthly rainfall; sard, sardine larvae density; SST, sea surface temperature; wind, easterly wind speed; zooplk, mesozooplankton density; $G C V$, Generalized Cross Validation

current study presents, for the first time, which environmental variables are affecting the anchovy and sardine larvae populations in the region. Easterly wind speed and zooplankton density were the only environmental variables that presented a significant change between the pre- and post-drought periods, increasing after the drought. We show here that, together with wind, it was rainfall, chlorophyll $a$ and sardine larvae abundance, and the interactions between temperature and clorophyll $a$ and between temperature and sardine larvae abundance, the variables that better explained the changes in the anchovy larvae population. Regarding the sardine larvae population, its variability was better explained by wind speed than by any other environmental variable.

In South African waters, adult anchovy may be found inshore but are more often found over $100 \mathrm{~km}$ from the coastline, whereas adult sardines tend to live within $50 \mathrm{~km}$ of the coast, and are commonly found inshore (Barange et al. 1999; van der Lingen et al. 2001; Fairweather et al. 2006). While anchovies are indeed spawning in Algoa Bay (Hutchings et al. 2002; Van der Lingen and Huggett 2003), sardines spawn only sporadically along the East coast of South Africa (Hutchings et al. 2002; Connell 2010) because adult sardine congregate mostly around the inshore regions of the western Agulhas Bank (Beckley and van der Lingen 1999). The relatively low abundance of sardine larvae found within Algoa Bay reinforces the fact that this is not a primary spawning area for sardine (van der Lingen et al. 2001). The warm waters of the east and south coast of South Africa, including Algoa Bay, promote the increase of anchovy larvae abundance (van der Lingen et al. 2001). While both sardine and anchovy use this bay to spawn and complete their pelagic phase, anchovy larvae are far more abundant as they are less tolerant of the cold waters along the west coast and therefore thrive in the warmer waters of Algoa Bay.

Larvae of anchovy and sardine collected for this study ranged 1.7-8.9 $\mathrm{mm}$ and 2.9-9.5 $\mathrm{mm} \mathrm{SL}$, respectively, and thus are unlikely to be able to consume mesozooplankton (Muck et al. 1989; Costalago et al. 2012). Therefore, an increase in larval abundance following a proliferation in this food source should not be expected. This helps to explain why a significant effect of mesozooplankton on the abundances of anchovy and sardine larvae was not detected, as fish at this size are 
a
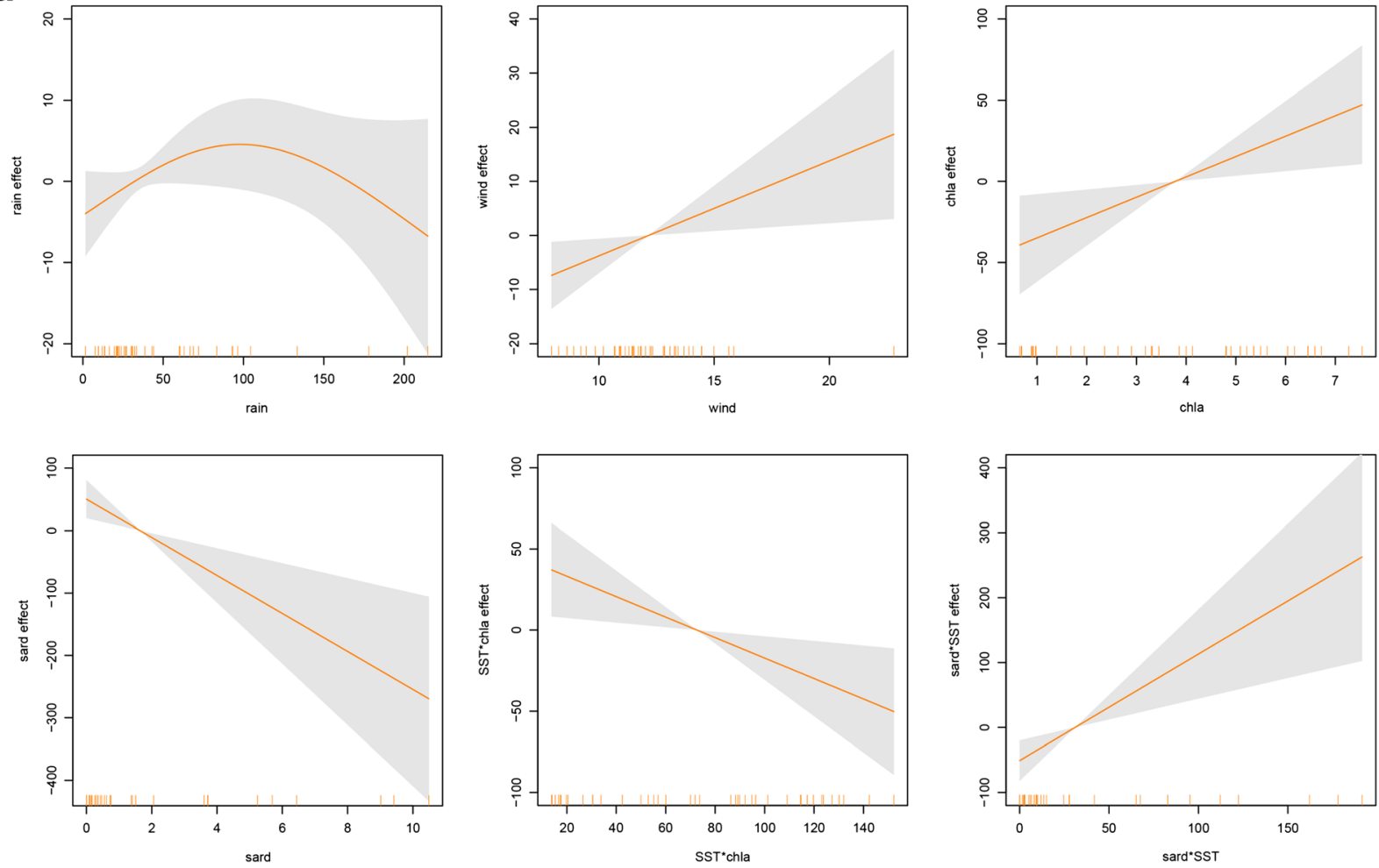

b

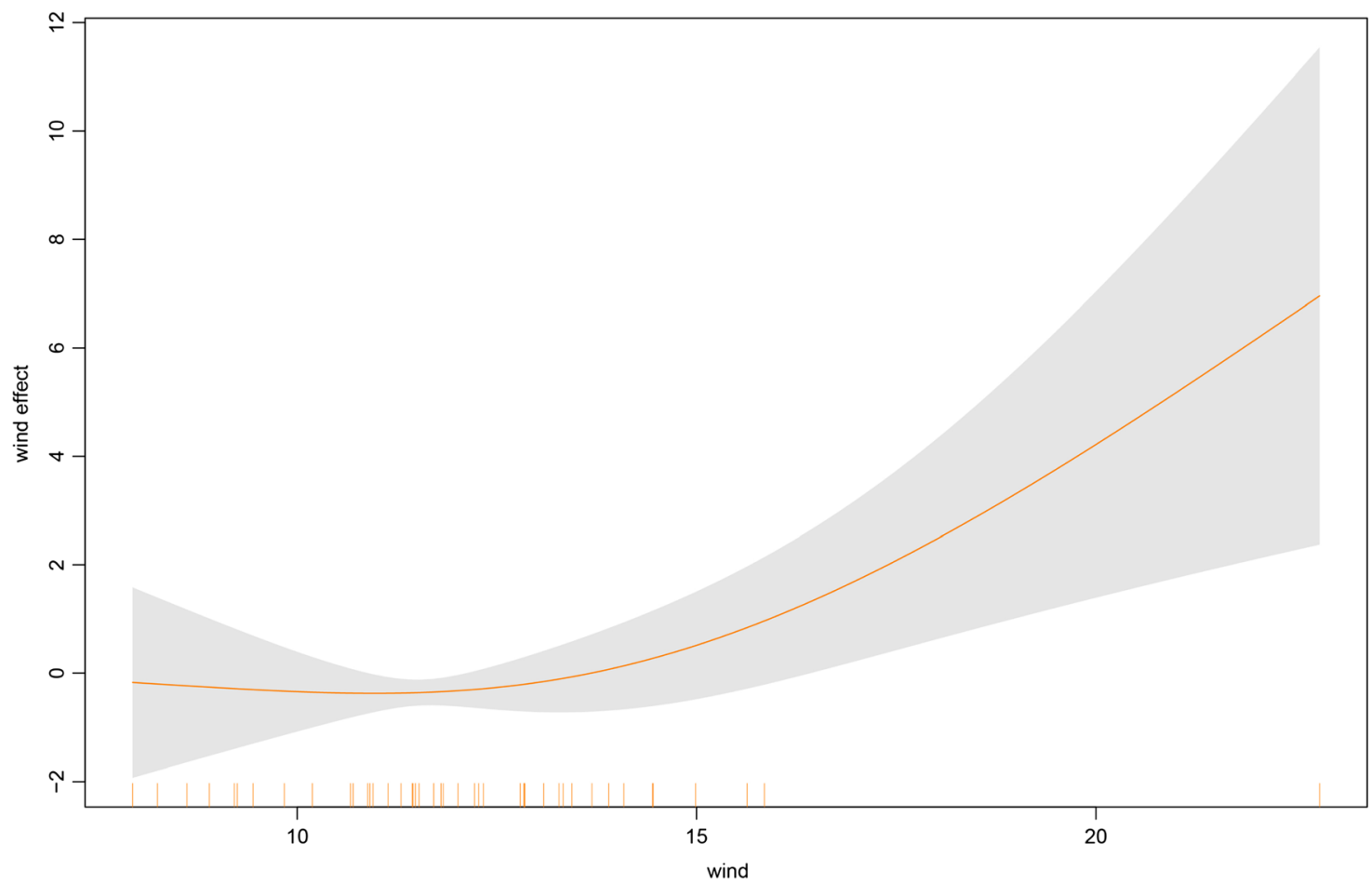

feeding mainly on microplankton. Microplankton usually represents $70-90 \%$ of total zooplankton in coastal areas, but when the total zooplankton abundance increases, there is generally a decrease in the 
Fig. 4 Best fit multivariate generalized additive model (GAM) terms showing the estimated partial effects (solid line) that each predictor variable has on the abundance of (a) anchovy (model A3 as in Table 1) and (b) sardine (model S6 as in Table 1) larvae during the entire period of study. The grey-shaded areas are the 95\% confidence intervals, and the small lines along the $\mathrm{x}$ axis indicate the location of the sample plots. anch: anchovy larvae abundance; chla: chlorophyll $a$ concentration; rain: monthly rainfall; sard: sardine larvae abundance; SST: sea surface temperature; wind: easterly wind speed; zooplk: mesozooplankton density

microplankton/mesozooplankton ratio, probably due to the higher predation of mesozooplankton on microplankton (Calbet et al. 2001). Thus, a moderate abundance of mesozooplankton in Algoa Bay might benefit the populations of small clupeid larvae through an increase in microplankton.

Both larval anchovy abundance and mesozooplankton density were significantly higher during the post-drought period than during the pre-drought period, suggesting that mesozooplankton might influence anchovy larvae positively. The explanation for that is likely to be related to the adults spawning in Algoa Bay. Anchovy adults feed mostly on mesozooplankton (van der Lingen et al. 2006; Costalago et al. 2012), and thus a higher prey availability ultimately translates into a greater adult presence and thereby egg production (Kjesbu et al. 1996).

Chlorophyll $a$ is a measure of phytoplankton in surface waters (Shannon et al. 1984). Higher chlorophyll $a$ concentrations have been associated with feeding grounds of both sardine and anchovy (van der Lingen et al. 2006; Bellido et al. 2008). Higher easterly wind speeds, which are related to upwelling events and higher chlorophyll $a$ concentration (Goschen and Schumann 1995), alter the dynamics of the surface waters creating currents and turbulence. That turbulence may harm small fish larvae and the currents may result in offshore transport (Boyd et al. 1992; Hutchings et al. 2002) away from the sampling sites. However, the important input of nutrients brought up by the upwelling events following intense periods of easterly winds have an overall positive effect on the abundance of anchovy larvae, as shown by the GAM.

Low levels of chlorophyll $a$ during summer in Algoa Bay are related to strong southwesterly winds, which favor mixing of the water column and suppress upwelling activity. On the other hand, strong northeasterly winds in the region promoteupwellings (Schumann et al. 1991). The upwelling events associated with easterly winds occurred mainly in the post-drought years
(McInnes et al. 2017). This supports the results of our GAMs, which show a significant influence of high levels of easterly wind speed and Chl $a$ concentration on anchovy larvae. Although both anchovy and sardine in Algoa Bay seem to spawn throughout the year, a higher abundance of anchovy larvae is generally observed during the summer. Furthermore, moderate levels of turbulence are important for larval fish, since this developmental stage is far more dependent than adult fish on winds and tides as a means of prey encounter (MacKenzie and Leggett 1991).

The GAMs showed that moderate levels of levels in Algoa Bay benefit the size of the anchovy larvae population. This is likely due to the nutrient inflow from the rivers into the Bay (Pattrick and Strydom 2008). On the contrary, low, but also very high amounts of rain seemed to have a negative effect on the fish larvae. The drought period might have limited the survival of the larvae and the recruitment of anchovy and sardine in the Bay, thus keeping the larval abundance registered after the drought from increasing any further. Possibly, this effect has been counterbalanced by the moderate rains in the post-drought period, but especially by the relatively strong easterly winds. Moreover, McInnes et al. (2017) described an anusual spike in Chl $a$ in Algoa Bay during April-May 2012 and again in May 2013, and they linked it to water pulses offshore in the Agulhas Current and the associated influxes of cool, upwelled waters into the Bay. McInnes et al. (2017) claimed that, through an enhancement in the regional primary production, these pulses led to the increase in pelagic fish abundance, especially around Bird Island.

Another environmental variable which can potentially influence the abundance of anchovy and sardine larvae in the Bay is the sea surface temperature (SST). The mean SST in the southern Benguela Current system ranges from $14.0-17.8^{\circ} \mathrm{C}$ during calm conditions but decreases to $9.3-10.2{ }^{\circ} \mathrm{C}$ during upwelling events (Pitcher et al. 1996), which is far lower than the mean SST for Algoa Bay. This temperature variability in the southern Benguela Current system affects the spawning success of sardine and anchovy (van der Lingen and Huggett 2003), where anchovy prefer to spawn in warmer waters while sardine can spawn at a wider range of temperatures (van der Lingen et al. 2001), but prefer cooler temperatures. The temperature of the water not only affects spawning success but also the survival of larval stages (Clemmesen et al. 2003; Green and Fisher 2004). The larval phase of pelagic fish is susceptible to 
changes in metabolism associated with variation in temperature (Rombough 1997). This, in turn, affects physiological processes, growth, development and behavioural responses (Green and Fisher 2004).

In the Benguela Current, sardine (Sardinops sagax) spawn successfully between $15.2-20.5^{\circ} \mathrm{C}$ and anchovy (Engraulis encrasicolus) spawn between 17.4 $21.1{ }^{\circ} \mathrm{C}$ (Van der Lingen and Huggett 2003). Sardine spawn along the South African coast throughout most of the year (Coetzee et al. 2008), peaking in the spring and summer months (Crawford 1981), and are relatively non-specific in their choice of spawning areas and may successfully spawn on the west and south coast (van der Lingen et al. 2001; Coetzee et al. 2008). In contrast, anchovy spawning peaks in summer and eggs are rarely found in the autumn and winter months (Crawford 1981). Once sexual maturity is reached, the temperature preference of each species changes, with sardine more likely to be found in warmer waters closer to the shore line, and anchovy more likely to be found farther offshore in cooler, oceanic waters (van der Lingen et al. 2001).

In other areas of the world where anchovy and sardine species co-exist, the larvae of both species are usually not found together [e.g., in the Mediterranean Sea E. encrasicolus and Sardina pilchardus spawn at different times of the year so that their larvae do not occur simultaneously (Palomera et al. 2007)]. When the early life stages of both anchovy and sardine in non-upwelling regions occur together, competition for food is more likely to take place (Costalago et al. 2012; Costalago et al. 2014) compared to upwelling areas where plankton would be more abundant [e.g., Benguela Current system (van der Lingen et al. 2006)]. This competition for relatively scarce resources is further exacerbated in clupeid larvae, since anchovy and sardine start having different diets only after they have developed their gill rakers at an advanced juvenile stage (Costalago et al. 2012; Costalago et al. 2014). Therefore, competition for food might also be an important factor limiting the abundance of anchovy and/or sardine larvae in Algoa Bay. Given the difficulty to measure inter-species competition, which, in addition, is rarely independent of other factors (Hollowed et al. 2000), the estimation of this parameter requires indirect ways of quantification. Food limitation, predation risk, foraging behavior and carrying capacity of the system are just some examples of the ecological parameters commonly connected to competition for food (Hollowed et al. 2000; Fulton et al. 2005; Johnson 2007).

The present analysis shows that larval abundance of sardine and anchovy in Algoa Bay can be at least partially modelled using a limited number of environmental predictors, and provides an important update in the state-of-the-art of the marine ecosystem. Moreover, the high relevance of small pelagic fish in the marine ecosystem and in the economy of the region and the urgent requirement of scientific information to help assess the risks and/or benefits of Marine Protected Areas (Pichegru et al. 2012; Sherley et al. 2013) or of fish farming activities (Bloom 2012, 2013; Hutchings et al. 2013) in Algoa Bay make the present study particularly necessary.

Acknowledgements DC was supported by postdoctoral fellowships from Nelson Mandela Metropolitan University and from the National Research Foundation (NRF) of South Africa. Funding for all data collection was provided by the NRF and the Department of Agriculture, Forestry and Fisheries of South Africa (DAFF). Additional funding was obtained from the Department of Environmental Affairs of South Africa (DEA). This study was conducted under the approval, and with the ethical standards, of the Nelson Mandela Metropolitan University, DAFF and DEA.

Open Access This article is distributed under the terms of the Creative Commons Attribution 4.0 International License (http:// creativecommons.org/licenses/by/4.0/), which permits unrestricted use, distribution, and reproduction in any medium, provided you give appropriate credit to the original author(s) and the source, provide a link to the Creative Commons license, and indicate if changes were made.

\section{References}

Bakun A (2006) Wasp-waist populations and marine ecosystem dynamics: Navigating the "predator pit" topographies. Prog Oceanogr 68:271-288

Barange M, Hampton I, Roel BA (1999) Trends in the abundance and distribution of anchovy and sardine on the South African continental shelf in the 1990s, deduced from acoustic surveys. S Afr J Mar Sci 21(1):367-391

Batchelor AL, Ross GJB (1984) The diet and implications of dietary change of Cape gannets on Bird Island, Algoa Bay. Ostrich 55:45-63

Beaugrand G, Reid PC (2003) Long-term changes in phytoplankton, zooplankton and salmon related to climate. Glob Chang Biol 9(6):801-817

Beckley LE, van der Lingen CD (1999) Biology, fishery and management of sardines (Sardinops sagax) in southern African waters. Mar Freshw Res 50(8):955-978

Bellido JM, Brown AM, Valavanis VD, Giráldez A, Pierce GJ, Iglesias M, Palialexis A (2008) Identifying essential fish 
habitat for small pelagic species in Spanish Mediterranean waters. Hydrobiologia 612(1):171-184

Bergenius MA, Meekan MG, Robertson RD, McCormick MI (2002) Larval growth predicts the recruitment success of a coral reef fish. Oecologia 131(4):521-525

Bloom J (2012) Baseline socio-economic assessment for the development of aquaculture development zones for mariculture fish farming in Algoa Bay. Draft Consultative Report prepared for CapeEAPrac (Pty) Ltd, George, p 42

Bloom J (2013) Socio-economic impact assessment for the proposed Algoa Bay sea-based aquaculture development zones, Port Elizabeth. Draft Consultative Report prepared for CapeEAPrac (Pty) Ltd, George, p 88

Boyd AJ, Taunton-Clark J, Oberholster GPJ (1992) Spatial features of the near-surface and midwater circulation patterns off western and southern South Africa and their role in the life histories of various commercially fished species. S Afr J Mar Sci 12(1):189-206

Bremner JM (1991) Logarithmic spiral beaches with emphasis on Algoa Bay. In: Bremner JM, Du Plessis A, Glass JGK, Day RW (eds) Algoa Bay - Marine Geoscientific Investigations. Bulletin of the Geological Survey of South Africa 100, p 147-164

Calbet A, Garrido S, Saiz E, Alcaraz M, Duarte CM (2001) Annual zooplankton succession in coastal NW Mediterranean waters: the importance of the smaller size fractions. J Plankton Res 23(3):319-331

Caley MJ, Carr MH, Hixon MA, Hughes TP, Jones GP, Menge BA (1996) Recruitment and the local dynamics of open marine populations. Annu Rev Ecol Syst 27(1):477-500

Clemmesen C, Bühler V, Carvalho G, Case EG, Hauser L, Svaasand T (2003) Variability in condition and growth of Atlantic cod larvae and juveniles reared in mesocosms: environmental and maternal effects. J Fish Biol 62(3):706-723

Coetzee JC, van der Lingen CD, Hutchings L, Fairweather TP (2008) Has the fishery contributed to a major shift in the distribution of South African sardine? ICES J Mar Sci 65(9): $1676-1688$

Connell AD (2010) A 21-year ichthyoplankton collection confirms sardine spawning in KwaZulu-Natal waters. Afr J Mar Sci 32(2):331-336

Costalago D, Tecchio S, Palomera I, Álvarez-Calleja I, OspinaÁlvarez A, Raicevich S (2011) Ecological understanding for fishery management: Condition and growth of anchovy late larvae during different seasons in the Northwestern Mediterranean. Estuar Coast Shelf Sci 93(4):350-358

Costalago D, Navarro J, Álvarez-Calleja I, Palomera I (2012) Ontogenetic and seasonal changes in the feeding habits and trophic levels of two small pelagic fish species. Mar Ecol Prog Ser 460:169-181

Costalago D, Palomera I, Tirelli V (2014) Seasonal comparison of the diets of juvenile European anchovy Engraulis encrasicolus and sardine Sardina pilchardus in the Gulf of Lions. J Sea Res 89:64-72

Crawford RJM (1981) Distribution, availability and movements of anchovy Engraulis capensis off South Africa, 1964-1976. Fisheries bulletin; contributions to oceanography and fisheries biology - South Africa, Dept. of Agriculture and Fisheries, Sea Fisheries Institute
Cury P, Roy C (1989) Optimal environmental window and pelagic fish recruitment success in upwelling areas. Can J Fish Aquat Sci 46:670-680

Cury P, Bakun A, Crawford RJ, Jarre A, Quiñones RA, Shannon LJ, Verheye HM (2000) Small pelagics in upwelling systems: patterns of interaction and structural changes in "wasp-waist" ecosystems. ICES J Mar Sci 57:603-618

Cushing DH (1996) Towards a Science of Recruitment in Fish Populations. Ecology Institute, Oldendorf/Luhe, p 175

Dali LOB (2011) Initial investigations into dynamics of mesozooplankton community structure in Algoa Bay, South Africa. PhD Thesis, Rhodes University, South Africa

Daskalov GM, Boye DC, Roux JP (2003) Relating sardine Sardinops sagax abundance to environmental indices in northern Benguela. Prog Oceanogr 59(2):257-274

David JHM (1987) Diet of the South African fur seal (1974-1985) and an assessment of competition with fisheries in southern Africa. S Afr J Mar Sci 5(1):693-713

Dent MC, Lynch SD, Schulze RE (1987) Mapping mean annual and other rainfall statistics over southern Africa. Agricultural Catchments Research Unit Report, no. 27. University of Natal, South Africa

Fairweather TP, van der Lingen CD, Booth AJ, Drapeau L, van der Westhuizen JJ (2006) Indicators of sustainable fishing for South African sardine Sardinops sagax and anchovy Engraulis encrasicolus. Afr J Mar Sci 28(3-4):661-680

Fulton EA, Smith AD, Punt AE (2005) Which ecological indicators can robustly detect effects of fishing? ICES J Mar Sci 62(3):540-551

Goschen WS (1991) Ocean dynamics associated with prominent capes and bays off the south coast of South Africa. $\mathrm{PhD}$ Thesis, University of Port Elizabeth, South Africa

Goschen WS, Schumann EH (1988) Ocean current and temperature structures in Algoa Bay and beyond in November 1986. S Afr J Mar Sci 7:101-116

Goschen WS, Schumann EH (1994) An Agulhas Current intrusion into Algoa Bay during August 1988. S Afr J Mar Sci 14(1): $47-57$

Goschen WS, Schumann EH (1995) Upwelling and the occurrence of cold water around Cape Recife, South Africa. S Afr J Mar Sci 16:57-67

Goschen WS, Schumann EH (2011) The physical oceanographic processes of Algoa Bay, with emphasis on the western coastal region. South African Environmental Observation Network (SAEON) and the Institute of Maritime Technology (IMT). IMT document number: PO106-10000-730002

Goschen WS, Schumann EH, Bernard KS, Bailey SE, Deyzel SHP (2012) Upwelling and ocean structures off Algoa Bay and the south-east coast of South Africa. Afr J Mar Sci 34(4): 525-536

Green BS, Fisher R (2004) Temperature influences swimming speed, growth and larval duration in coral reef fish larvae. $\mathrm{J}$ Exp Mar Biol Ecol 299(1):115-132

Hollowed AB, Bax N, Beamish R, Collie J, Fogarty M, Livingston P, Pope J, Rice JC (2000) Are multispecies models an improvement on single-species models for measuring fishing impacts on marine ecosystems? ICES J Mar Sci 57(3):707719

Houde ED (2008) Emerging from Hjort's shadow. J Northwest Atl Fish Sci 41:53-70 
Hutchings L, Beckley LE, Griffiths MH, Roberts MJ, Sundby S, van der Lingen CD (2002) Spawning on the edge: spawning grounds and nursery areas around the southern African coastline. Mar Freshw Res 53(2):307-318

Hutchings K, Porter SN, Clark BN (2013) Marine specialist report. Marine Aquaculture Development Zones for Fin Fish Cage Culture in the Eastern Cape: Description of the Affected Environment. Update

Johnson MD (2007) Measuring habitat quality: a review. Condor 109(3):489-504

Kjesbu OS, Solemdal P, Bratland P, Fonn M (1996) Variation in annual egg production in individual captive Atlantic cod (Gadus morhua). Can J Fish Aquat Sci 53(3):610-620

Leggett WC, Deblois E (1994) Recruitment in marine fishes: is it regulated by starvation and predation in the egg and larval stages? Neth J Sea Res 32(2):119-134

Lukey JR, Booth AJ, Froneman PW (2006) Fish population size and movement patterns in a small intermittently open South African estuary. Estuar Coast Shelf Sci 67(1):10-20

Lutjeharms JRE (1981) Features of the Southern Agulhas Current circulation from satellite remote-sensing. S Afr J Sci 77(5): 231-236

MacKenzie BR, Leggett WC (1991) Quantifying the contribution of small-scale turbulence to the encounter rates between larval fish and their zooplankton prey: effects of wind and tide. Mar Ecol Prog Ser 73(2):149-160

McInnes AM, Ryan PG, Lacerda M, Deshayes J, Goschen WS, Pichegru L (2017) Small pelagic fish responses to fine-scale oceanographic conditions: implications for the endangered African penguin. Mar Ecol Prog Ser 569:187-203

Muck PE, Rojas de Mendiola B, Antonietti EM (1989) Comparative studies on feeding in larval anchoveta (Engraulis ringens) and sardine (Sardinops sagax). In The Peruvian upwelling ecosystem: dynamics and interactions, ICLARM Conference Proceedings, vol 18, pp 86-96

Olivar PM, Shelton PA (1993) Larval fish assemblages of the Benguela Current. Bull Mar Sci 53(2):450-474

Palomera I, Olivar MP, Salat J, Sabatés A, Coll M, García A, Morales-Nin B (2007) Small pelagic fish in the NW Mediterranean Sea: an ecological review. Prog Oceanogr 74(2):377-396

Pattrick P, Strydom NA (2008) Composition, abundance, distribution and seasonality of larval fishes in the shallow nearshore of the proposed Greater Addo Marine Reserve, Algoa Bay, South Africa. Estuar Coast Shelf Sci 79(2):251-262

Pichegru L, Grémillet D, Crawford RJM, Ryan PG (2010) Marine no-take zone rapidly benefits endangered penguin. Biol Lett 6(4):498-501

Pichegru L, Ryan PG, Van Eeden R, Reid T, Grémillet D, Wanless R (2012) Industrial fishing, no-take zones and endangered penguins. Biol Conserv 156:117-125

Pikitch EK, Rountos KJ, Essington TE, Santora C, Pauly D, Watson R, Sumaila UR, Dee Boearsma P, Boyd IL, Conover DO, Cury P, Heppell SS, Houde ED, Mangel M, Plagányi E, Sainsbury K, Steneck RS, Geers TM, Gownaris N, Munch SB (2014) The global contribution of forage fish to marine fisheries and ecosystems. Fish Fish 15(1):43-64
Pitcher GC, Richardson AJ, Korrubel JL (1996) The use of sea temperature in characterizing the mesoscale heterogeneity of phytoplankton in an embayment of the southern Benguela upwelling system. J Plankton Res 18(5):643-657

Rombough PJ (1997) The effects of temperature on embryonic and larval development. In: Wood CM, McDonald DG (eds) Global warming: implications for freshwater and marine fish. Cambridge University Press, Cambridge, pp 177-223

Roy C, van der Lingen CD, Coetzee JC, Lutjeharms JRE (2007) Abrupt environmental shift associated with changes in the distribution of Cape anchovy Engraulis encrasicolus spawners in the southern Benguela. Afr J Mar Sci 29(3): 309-319

Schumann EH, Illenberger WK, Goschen WS (1991) Surface winds over Algoa Bay, South Africa. S Afr J Sci 87(5): 202-207

Shannon LV, Hutchings L, Bailey GW, Shelton PA (1984) Spatial and temporal distribution of chlorophyll in southern African waters as deduced from ship and satellite measurements and their implications for pelagic fisheries. S Afr J Mar Sci 2(1): 109-130

Sherley RB, Underhill LG, Barham BJ, Barham PJ, Coetzee JC, Crawford RJ, Dyer BM, Leshoro TM, Upfold L (2013) Influence of local and regional prey availability on breeding performance of African penguins Spheniscus demersus. Mar Ecol Prog Ser 473:291-301

Smit AJ, Roberts M, Anderson RJ, Dufois F, Dudley SF, Bornman TG, Olbers J, Bolton JJ (2013) A coastal seawater temperature dataset for biogeographical studies: large biases between in situ and remotely-sensed data sets around the coast of South Africa. PLoS One 8(12):e81944

Van der Lingen CD, Huggett JA (2003) The role of ichthyoplankton surveys in recruitment research and management of South African anchovy and sardine. In: Browman HI, Skiftesvik AB (eds) Proceedings of the 26th Annual Larval Fish Conference. Institute of Marine Research, Bergen, pp 303-343

Van der Lingen CD, Hutchings L, Merkle D, Van der Westhuizen JJ, Nelson J (2001) Comparative spawning habitats of anchovy (Engraulis capensis) and sardine (Sardinops sagax) in the southern Benguela upwelling ecosystem. Spatial Processes and Management of Marine Populations, Fairbanks, AK University of Alaska Sea Grant, AK-SG-011158 02, pp 185-209

Van der Lingen CD, Hutchings L, Field JG (2006) Comparative trophodynamics of anchovy Engraulis encrasicolus and sardine Sardinops sagax in the southern Benguela: are species alternations between small pelagic fish trophodynamically mediated? Afr J Mar Sci 28(3-4):465-477

Whitfield AK (1998) Biology and ecology of fishes in South African Estuaries. In: Ichthyological Monographs of the JLB Smith Institute for Ichthyology, No. 2, Grahamstown, p 232

Wood SJR (2001) mgcv: GAMs and Generalized Ridge Regression for R. R News 1(2):20-25

Young DD, Cockcroft VG (1994) Diet of common dolphins (Delphinus delphis) off the south-east coast of southern Africa: opportunism or specialization? J Zool 234:41-53 